\title{
Lessons Learnt from the 2012 Flood Disaster: Implications for Post-flood Building Design and Construction in Yenagoa, Nigeria
}

\author{
Warebi Gabriel Brisibe*, Tonye Dagogo Pepple \\ Department of Architecture, Faculty of Environmental Sciences, Rivers State University, Port-Harcourt, Nigeria
}

Copyright $(\mathrm{C} 2018$ by authors, all rights reserved. Authors agree that this article remains permanently open access under the terms of the Creative Commons Attribution License 4.0 International License

\begin{abstract}
Studies have shown that most parts of Yenagoa, the Bayelsa State capital fall within the high-risk flood zone of Nigeria and are susceptible to annual flooding. However, the 2012 flood was unusual in magnitude and led to the inundation of entire communities, the destruction of buildings and infrastructure. About five years have elapsed since the floods and new construction projects have resumed in some of the hardest hit areas of Yenagoa. This paper draws on data from a survey of 400 new residential dwellings around areas hardest hit by the flood in Yenagoa. The survey involved interviews with home owners and developers in selected areas, to investigate possible lessons learnt in building design, material use and construction in the region. The results of the survey show the percentage of developers who took precautionary measures in increasing flood resilience and those who did not; the factors that have influenced these decisions and level of professional involvement.
\end{abstract}

Keywords Architectural Design, Flooding, Building Construction, Resilience, Adaptability

\section{Introduction}

Bayelsa State is subject to perennial flooding as a result of low terrain levels, high rainfall intensities, high tidal levels, dam failures and overflow of the River Niger and its tributaries. In addition to the above factors, flooding in Yenagoa which is the capital city is accentuated by sedimentation and urbanisation activities such as construction of roads, erection of buildings and ineffective drainage and waste management systems. Like most flood prone areas it experiences frequent floods in various magnitudes, ranging from minor to extreme flood events.

The 2012 flood was one of such extreme flood event and it occurred as a result of a dam release. Pent up flood waters were released from the Lagdo dam in Cameroun and the resulting deluge affected most downstream communities along the River Niger, its main tributary which is the Benue River as well as its main discharge outlet the Niger Delta. High-risk flood zones in the Niger Delta like Yenagoa, the Bayelsa State capital was adversely affected with considerable damage to buildings and infrastructure.

The consensus amongst most scholars and experts in the area of flooding is that, the best strategy to avoid flood damage is to avoid flood prone areas, since absolute flood protection is impossible $[1,2]$. But in cases like Yenagoa, where settlements already existed before extreme flood events are experienced and new building developments continue with increased urbanization, Kreibich et al states that flood damage must be kept as low as possible [3]. New developments, especially residential buildings are springing up each day as the city experiences increased growth.

As such, the aim of this study is to investigate if there have been lessons learnt from the 2012 flood by examining if precautionary measures were taken by recent developers to make the buildings more resilient or adaptable to flooding. To achieve this aim, this study examines two pertinent questions;

1. Have there been any lessons learned to make subsequent new buildings more flood resilient or adaptable?

2. If so, what are these lessons learned and how are they reflected in the architectural designs and construction techniques in these new buildings?

\section{Literature Review}

Blanco and Schanze opine that flood impact on buildings can be described by the degree of experienced harm of its materials and structures and the deterioration of its physical functions [25]. The damaging effects of floods on buildings 
have been described by a number of scholars. Nikolowski et al [10] listed damage types as;

- Saturation of building components

- Destruction of water-sensitive building components

- Destruction of building components through hydrostatic pressure

- Damage to building services

While Naumann et al [8] classified the damage types as;

- Moisture/ water damages

- Structural damages

- Contamination damages

The idea of lessons learned is to undertake a review of past performances and be better prepared in the event of another extreme flood. Kreibirch et al explained that preparedness consisted of preventive, precautionary and preparative measures [3]. The concept of Building-Back-Better (BBB) is also an aspect of lessons learnt as precautionary measures are taken in reconstruction or rebuilding to make the buildings better by being more resilient than they were before. A survey from an earlier study of 140 households in a flood prone area of Australia revealed that precautionary measures taken by residents in the building of their houses had helped reduce actual damage by $52.4 \%$ [4]. A similar study was also conducted on why some residents take precautionary measures in building against floods and others do not [5]. The scholars developed a socio-psychological model based on what they referred to as protection motivation theory (PMT). Their study tried to analyze precautionary measure behaviours of residents based on;

- Perceptions of previous flood experiences

- Risk of future floods

- Reliability of public flood protection measures

This study tows a similar line in assessing precautionary measure behaviours of residents and developers in some high risk flood areas of Yenagoa. However, the difference is that this analysis is based on;

- Their personal perception of previous flood experiences as well as the perception of others

- The advice of Architects' or other building professionals

- Sensitization campaigns by government agencies on eminent future floods

This study also examines the types of precautionary measures taken to ensure building resilience against future extreme flood events. With regards to resilience, a study conducted in New Zealand revealed that future damage to buildings could be reduced by adopting appropriate building and foundation construction that are more resilient [6]. Also, Balmforth's work on flood resilient cities, highlighted the fact that based on lessons learnt from past floods, the way conventional buildings are currently constructed makes them highly vulnerable to destruction by floods waters [7]. Studies on the assessment of building resilience, vulnerability of buildings and resilience of different existing building types to floods have been conducted $[8,9,10]$, alongside studies on how to make buildings more resilient to flooding in all aspects. These include; improving the resilience of building materials and material technologies $[11,12,13]$; innovations in architectural designs for enhanced flood resilience [14, 15, $16,17]$; assessing and upgrading planning regulations and building codes to cover extreme flood events and climate change $[18,6]$; and even the role of building professionals in developing a flood resilient society [19].

All these studies emphasized a need to rethink building designs in flood prone areas towards a more resilient and adaptable approach. In the course of this study two terms were constantly resurfacing, the understanding of which is pivotal to this research and discussions in this field as a whole. These are 'Resilience' and 'Adaptability'. In this field of study, the possibility of interchangeably using these terms is a regular occurrence. As such, there is a need to clearly define these key terms to form the basis for discussion in this study.

\subsection{Definition of Terms}

Majority of the definitions used are those borrowed from reviews done by scholars that bear direct relevance to this study as well as a few which have been defined based on the study context. The terms 'Resilience' and 'Adaptability' as used in this paper are discussed in relation to flooding and building design.

Walker et al rightly observed that there are different interpretations of what is meant by resilience [20]. More so, it is sometimes used interchangeably with adaptability since these two form part of the related attributes of social ecological systems (SESs) yet they differ distinctively. This distinction is made evident in what constitutes flood resilient designs and flood adaptable designs. As such, it is has become necessary to assess these terms on their own right as well as in relation to flooding and buildings.

Resilience: Resilience as defined by Walker et al is the "capacity of a system to absorb disturbance and reorganize while undergoing change so as to still retain essentially the same function, structure, identity, and feedbacks" [20]. In relation to disaster, the International Strategy for Disaster Reduction (ISDR) defines resilience as;

The capacity of a system, community, or society potentially exposed to hazards to adapt by resisting or changing in order to reach and maintain an acceptable level of functioning and structure. This is determined by the degree to which the social system is capable of organizing itself to increase its capacity for learning from past disasters for better future protection and to improve risk reduction measures [21].

With regards to design, resilience involves creating buildings, communities and regions that mitigate threats of 
extreme weather and climate change by engineering buildings for severe wind and wave impacts and using materials that are waterproof or otherwise impermeable to water damage [15].

For the purpose of this study, resilience will be examined in relation to design against floods. As such, the data collected on resilient design measures would include; the use of waterproofing materials, waterproofing building products and flood protection methods such as barriers and defenses. This does not include the use of Damp Proof Membranes (DPM) which is a regular building feature that serves as a barrier for rising damp and other capillary actions. But it includes the use of waterproof cement admixtures, chemicals, asphalt or bitumen based linings, rubber or plastic sheet layers and other applications that increase resilience. This has been supported by a study suggesting that flood resilience of properties can be achieved by the use of adequate building materials, construction techniques and flood protection products amongst other measures [11].

Adaptability: Walker et al defines adaptability as the capacity of actors in a system to influence resilience [20]. This can be done by altering how the threshold affects the system and vice versa. Where adaptability differs from resilience is that it may not require measures that resist or stop flood waters but allows buildings function in spite of the floods. In terms of design, it requires designs to be more adjustable to users and functions in the event of floods. Kronenburg analyzed adaptable designs in the discussion on flexible architecture [22]. He suggests that for a building to adapt or be adaptable it ought to adjust to different functions, users and climates or even change in climate.

For this study, the data collected on design adaptability include; adaptable floor levels including buildings that float with increased flood levels, fortified foundations, adaptable building services and components including emergency escape hatches amongst others.

\section{Study Location}

Bayelsa State is located in the Niger Delta area which lies in the southern part of Nigeria and is a mixture of tropical rain forests and mangrove swamps. It has a total land area of 9,059 sq. km and the capital city Yenagoa, is one of eight Local government areas that make up its administrative structure. The climatic disposition of this region is tropical. It lies just above the Equator with an annual mean temperature range of $23.9^{\circ} \mathrm{C}-29.5^{\circ} \mathrm{C}$. The mean maximum temperature rarely exceeds $35^{\circ} \mathrm{C}$. Relative humidity is high and it increases as progression is made towards the coast.

The terrain is scarred by a network of tributaries, creeks and rivers, depositing their load into the Atlantic Ocean. There are 10 channels from which the waters of the River Niger are emptied into the Atlantic Ocean and 8 of these rivers run through Bayelsa State. The average rainfall experienced in this region is between $2000-2500 \mathrm{~mm}$ per annum or between 290-360 days of rainfall annually, culminating in floods. Bayelsa State is made up of eight Local Government Areas, including Yenagoa the State capital which is the study location as shown in fig. 1 below.

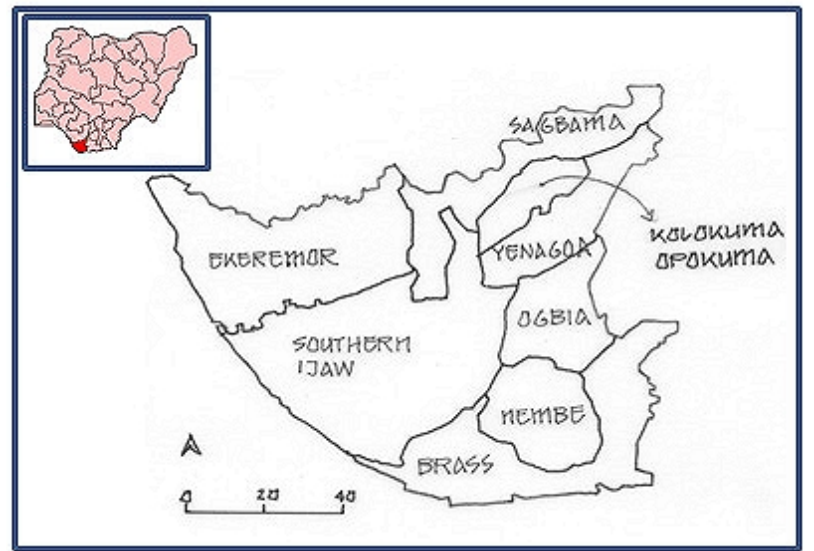

Figure 1. Map of Bayelsa State showing the eight Local Government Areas (LGAs) and the capital Yenagoa (Source: Author)

The areas within the study location in Yenagoa the Bayelsa State capital where newly built dwellings were identified include; Biogbolo, Okaka, Kpansia, Edepie, Etegwe and Akenfa. These locations were selected for two reasons. Firstly, they fall within the high flood risk zones which are areas prone to flooding and were badly affected by the floods that occurred in 2012. Secondly, over the last 5 years they have opened up for new residential developments for the middle and upper middle class more than any other locations in Yenagoa.

\section{Materials and Methods}

The study area involved communities that lie along some major creeks and their tributaries in Yenagoa; the Epie creek on the north which has a total of about 59 tributaries along its $30 \mathrm{~km}$ length feeding off it. The tributaries include the Akenfa creek, Agudama creek, Edepie creek and Okutukutu creek which runs southwards and joins up with the Ogbuko and Alagada creeks at Amarata (see fig 2). Buildings developed in areas along these creeks from 2013 to 2016 after the 2012 floods were targeted as survey samples. Data for this study was obtained as part of a larger study of building designs in flood prone areas of Yenagoa, Bayelsa State. Fieldwork for the study spanned about eight months between July 2016 and February 2017 with a team of four persons made up of the author and three field assistants. Each team member was assigned to communities along one of the four tributaries in the study area.

The survey adopted a house to house semi-structured interview approach. Four main questions were asked to 
each resident or their relatives present. Each interview lasted an average of $20 \mathrm{mins}$ but further time was allowed for narratives of experiences by respondents. The target was about 850 residents across seven highly affected communities but at the end just four hundred residents were interviewed. The respondents were asked about certain issues including;

- experiences of the flood as it affected their buildings or buildings of other people known to them

- levels of damage to the buildings
- if precautionary measures were taken in constructing their new buildings to make them more flood resilient

- And if so, what these specific measures are.

Information provided by the respondents were recorded in field notes at the point of interview and later collated. Data obtained from the survey were converted into tables from which percentages were obtained for each action undertaken by the respondents in response to questions asked. Discussions on precautionary measures for residents were based on percentage outcomes.

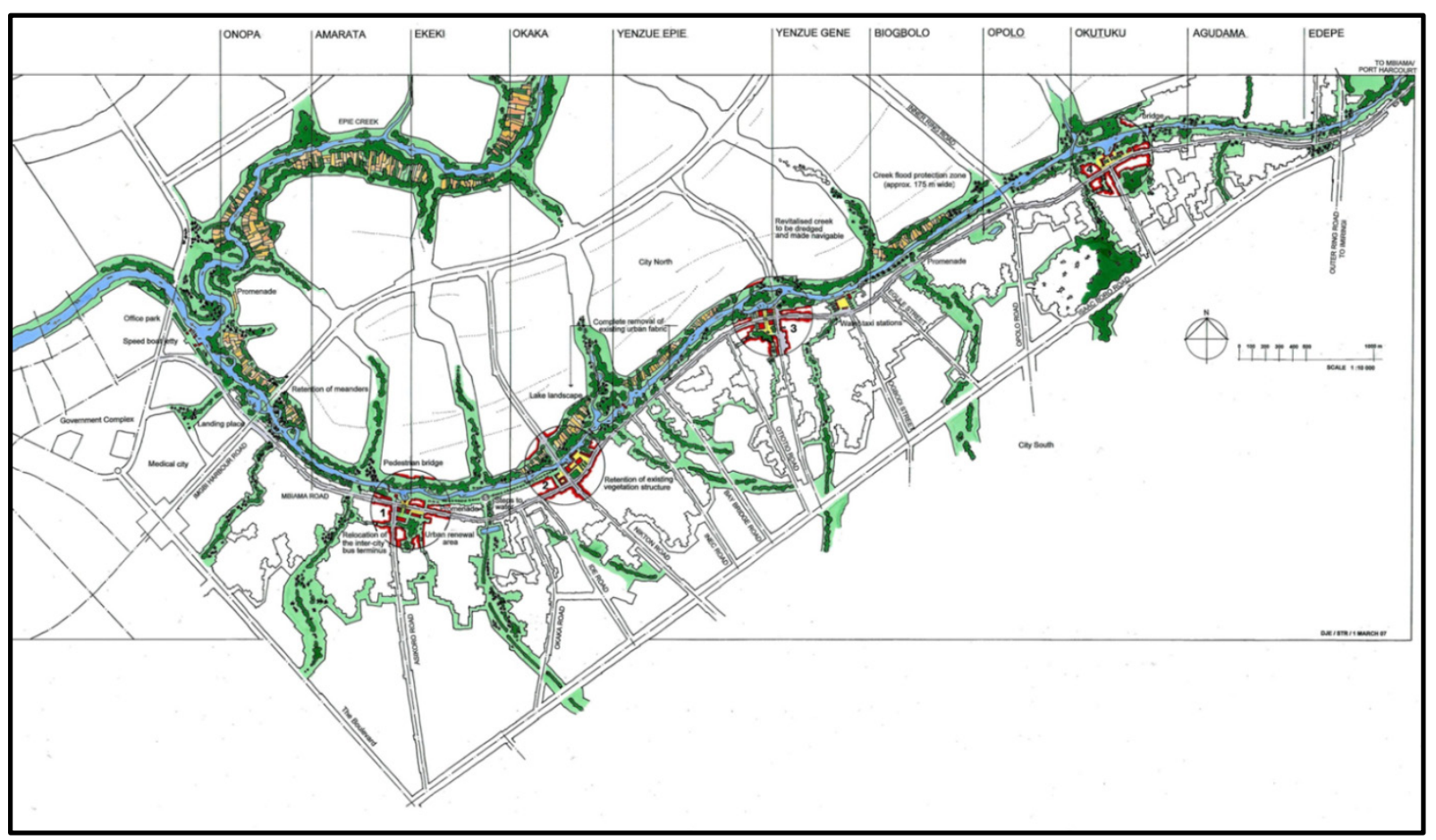

Figure 2. Map showing Epie creek and its tributaries in the study area (Courtesy: Albert Speer \& Partners) 


\section{Impact of the 2012 Floods on Buildings in Yenagoa}

After the 2012 floods, the Bayelsa state government set up an Infrastructure Advisory Committee (BSIAC) and a Post Flood Management Committee (PFMC). The aim was to assess the level of damage to buildings and infrastructure and advice on control and mitigation measures in the event of any future extreme floods. Part of the committees' report was that most of the existing buildings were ill-designed for flood resilience, hence the large extent of damage incurred.

Based on the official report by the Bayelsa State Infrastructure Advisory Committee (BSIAC) and Post Flood Management Committee PFMC, certain degrees of human fatalities and displacement of persons and communities were recorded. Some communities were either fully or partially inundated with flood heights ranging from $0.80 \mathrm{~m}$ to $2.5 \mathrm{~m}$ especially at the back swamps. It was also observed that most of the flooding resulted from overflow of nearby rivers, creeks, streams and other natural/artificial canals [23]. The comprehensive Post Disaster Needs Assessment conducted from November 2012 to March 2013 on the flood induced damage in Nigeria's Niger Delta with the support of the World Bank, United Nations and other agencies estimated the total value of infrastructure, physical and durable assets loss at $\$ 9.6 \mathrm{bn}$ [24].

However, the report from the PFMC did not specify the extent of damage to buildings in Yenagoa but it observed that buildings in several communities incurred different types and levels of damage due to the different levels of inundation they suffered. Some of the main conclusions deduced were the obvious facts that the level of damage incurred was directly proportional to the length of time the flood waters were sustained in the buildings. Also, the trend of building designs and construction within Yenagoa allowed for the possibility of several openings for ingress of flood waters into buildings. The report revealed that the avenues for flood water ingress into buildings include;

1. Backflow of sewage from overflooded septic tanks, soakaway pits and sewers bringing return discharge into buildings through sanitary appliances

2. Ingress through cracks in the walls
3. Doorways and windows

4. Seepage through unrendered external walls

5. Capillary action through hollow sandcrete blocks where no damp proof membrane was used.

However, the different types of direct damage incurred by buildings during the floods as specified by the PFMC report include:

1. Weakened or failed foundations

2. Caving-in of ground floors due to erosion of filling material such as mud or sand from under the foundation

3. Destruction of most timber based building products from doors to roof members depending on level of inundation or flood depth and duration of flood waters in contact with building

4. Damaged wall render and paint due to prolonged contact with floodwater

5. Damaged electrical wiring and fittings due to surface wiring technique widely used

6. Contamination of property with sewage, drains and chemicals from garages

In effect, one of the crucial lessons learnt was that the conventional way buildings in this region have been designed and built over the years makes them vulnerable to damage by flood waters in so many areas [23].

\section{Data Analysis}

The areas within the study locations in Yenagoa the Bayelsa State capital where newly built dwellings were identified include; Okaka, Biogbolo, Kpansia, Edepie, Etegwe and Akenfa. These locations were selected for two reasons. Firstly, they fall within the high flood risk zones which are areas prone to flooding and were badly affected by the floods that occurred in 2012. Secondly, over the last 4 years they have opened up for new residential developments for the middle and upper middle class more than any other locations in Yenagoa. Out of 400 residential buildings developed between 2013 and 2017 that were surveyed, 288 developers adopted one form of precautionary measure or the other against flooding. The remaining 112 developers did not adopt any precautionary measures against flooding to their buildings. 
Table 1. Data from survey of 400 new building developments in flood prone areas of Yenagoa

\begin{tabular}{|c|c|c|c|c|c|c|}
\hline \multirow[t]{2}{*}{1} & \multirow{2}{*}{$\begin{array}{l}\text { Flood resilient } \\
\text { measures used } \\
\text { No. of Persons out of } \\
288\end{array}$} & Water proofing & $\begin{array}{c}\text { Water proof } \\
\text { building products }\end{array}$ & $\begin{array}{l}\text { Water barrier and } \\
\text { defenses }\end{array}$ & Others & $\begin{array}{c}\text { Use of regular } \\
\text { Damp Proof } \\
\text { Membrane } \\
\end{array}$ \\
\hline & & $2(1 \%)$ & $3(1.5 \%)$ & Nil & Nil & $278(97.5 \%)$ \\
\hline \multirow{2}{*}{2} & \multirow{2}{*}{$\begin{array}{l}\text { Flood adaptable } \\
\text { measures used } \\
\text { No. of Persons out of } \\
288\end{array}$} & $\begin{array}{c}\text { Elevated floor } \\
\text { levels }\end{array}$ & $\begin{array}{c}\text { Flood adapted } \\
\text { spaces }\end{array}$ & $\begin{array}{l}\text { Flood adapted interior } \\
\text { fittings }\end{array}$ & $\begin{array}{c}\text { Flood adapted } \\
\text { building services }\end{array}$ & $\begin{array}{l}\text { Fortified } \\
\text { foundation }\end{array}$ \\
\hline & & $268(93 \%)$ & Nil & $12(4.2 \%)$ & $6(2.1 \%)$ & $179(62.2 \%)$ \\
\hline \multirow[t]{2}{*}{3} & \multirow{2}{*}{$\begin{array}{l}\text { Reason for taking } \\
\text { precautionary } \\
\text { measures } \\
\text { No. of Persons out of } \\
288\end{array}$} & $\begin{array}{l}\text { Architects' } \\
\text { /Professional } \\
\text { advice }\end{array}$ & $\begin{array}{l}\text { Previous personal } \\
\text { experience }\end{array}$ & $\begin{array}{c}\text { Sensitization } \\
\text { campaign by } \\
\text { Government or any } \\
\text { other agency }\end{array}$ & $\begin{array}{c}\text { Previous } \\
\text { experiences of } \\
\text { others }\end{array}$ & Other reasons \\
\hline & & $37(12.8 \%)$ & $78(27.1 \%)$ & $4(1.4 \%)$ & $169(58.7 \%)$ & Nil \\
\hline \multirow[t]{2}{*}{4} & \multirow{2}{*}{ 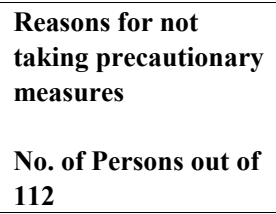 } & $\begin{array}{l}\text { No architects'/ } \\
\text { professional } \\
\text { advice }\end{array}$ & $\begin{array}{c}\text { Cost of } \\
\text { implementing } \\
\text { precautionary } \\
\text { measures }\end{array}$ & $\begin{array}{l}\text { No sensitization } \\
\text { campaign by } \\
\text { Government or any } \\
\text { other agency }\end{array}$ & $\begin{array}{c}\text { Do not believe } \\
\text { extreme flood } \\
\text { event will reoccur }\end{array}$ & Other reasons \\
\hline & & $9(8 \%)$ & $78(69.6 \%)$ & $9(8 \%)$ & $6(5.4 \%)$ & $10(9 \%)$ \\
\hline
\end{tabular}

From the survey of 400 new buildings, table 1 above reveals reasons why some developers took precautionary measures and the various flood resilient and adaptable methods used, as well as reasons why others did not take such measures. Figures 3-6 below show are pie charts that graphically represent the data shown in table 1 .

\section{Flood Adaptable Measures Used}

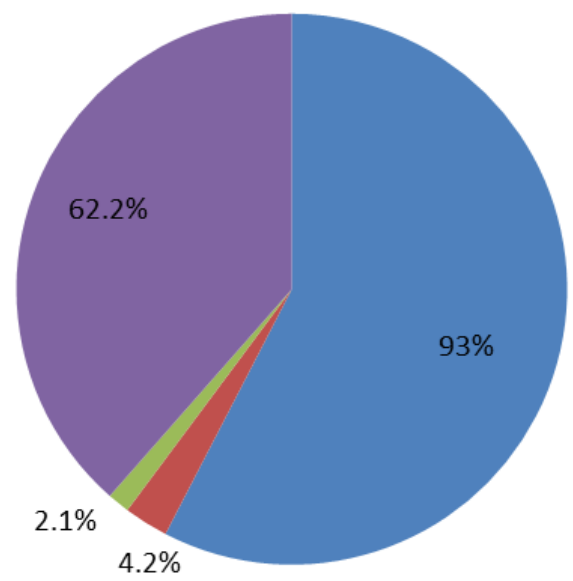

Elevated Floor levels

- Flood Adapted spaces

- Flood Adapted Building services

- Fortified Foundation

Figure 3. Pie chart showing flood adaptable measures used 


\section{Flood Resilient Measures used}

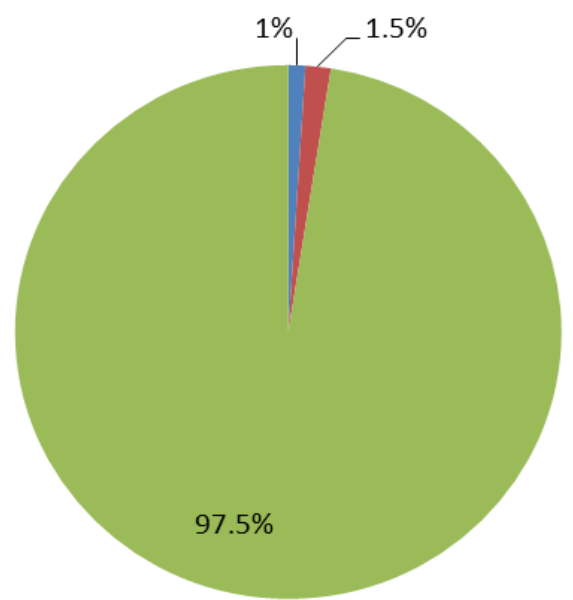

Water Proofing

Water Proof Building Products

- Use of Regular Damp Proof Membrane

Figure 4. Pie chart showing flood resilient measures used

\section{Reasons for Taking Precautionary Measures}

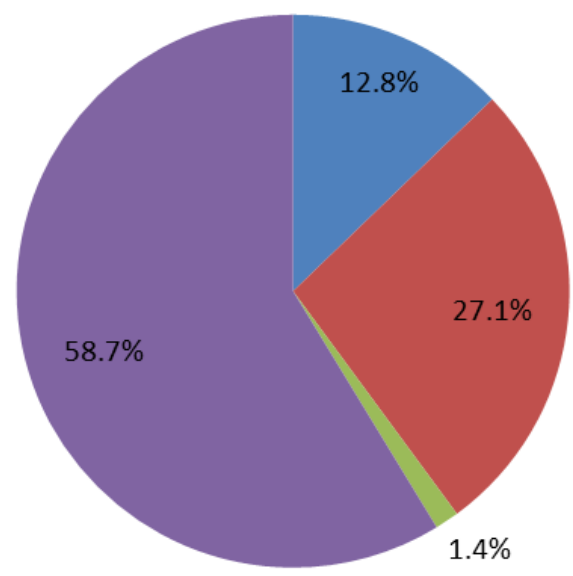

- Architects'/ Professional advice

n Previous Personal experience

- Sensitization campaign by Government or any other agency

- Previous experiences of others

Figure 5. Pie chart showing reasons why some developers and home-owners took precautionary measures against flood

\section{Reasons for not taking Precautionary Measures}

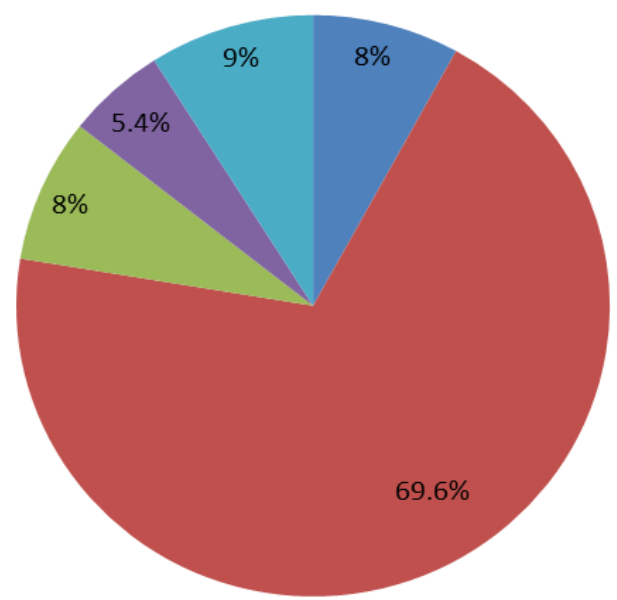

$$
\begin{aligned}
& \text { No Architects'/ professional } \\
& \text { advice } \\
& \text { Cost of Implementing } \\
& \text { Precautionary Measures } \\
& \text { No Sensitization campaign by } \\
& \text { Government or any other Agency } \\
& \text { Do not believe extreme flood } \\
& \text { event will reoccur } \\
& \text { Other reasons }
\end{aligned}
$$

Figure 6. Pie chart showing reasons why some developers and home-owners did not take precautionary measures against floods 
For flood adaptable measures, fig. 3 shows that about $93 \%$ of developers and home owners employed the use of elevated floor levels beyond the levels used prior to the floods. Within this number, $62.2 \%$ also fortified these elevated foundation walls and weakening caused by flood waters, with reinforced concrete. This data indicates an overlap of users, as some of the persons interviewed combined both the use of elevated floors and fortified foundations, making the total percentage exceed 100 . About $2.1 \%$ of the developers used flood adaptable building services as a means of reducing damage by backflow of sewage from over-flooded septic tanks, soak-away pits and sewers. The use of appliances such as back-flow stop valves or one-way gate valves stops return discharge into buildings from over-flooded pits.

Amongst developers and home owners who took flood resilient measures, the water proofing building products used are with specific reference to waterproof electrical fittings, but there was no record of anyone employing the use of wet proofing techniques, dry proofing or water barrier defenses. Also, the data indicates that there were no other measures taken to curtail ingress of flood waters through cracks or openings which was one of the main problems experienced during the past flood.

The data as shown in fig 5 indicates that of the number of developers who took precautionary measures, the advice of architects or other building professionals accounted for less than previous personal experiences or past experiences of others during the flood. While decisions based on information from campaigns disseminated by Government agencies on flood precautionary measures accounted for just a small fraction of the reasons precautionary measures were taken.

The most prevalent reason amongst those who had 'other reasons' for not taking any precautionary measures as shown in fig 6, was attributed to their beliefs or faith in supernatural protection from the floods or other such natural disasters. This emphasizes the role religion plays in the culture and decision making process of people in this region and Nigeria as a whole. There is also the minority who do not believe a flood of that magnitude is ever likely to reoccur except by another dam release. Most of the interviewees who hold this notion based their reasons on the local oral history of floods in the study area, not taking into account the possibility of increased floods due to climate change.

\section{Discussions}

The study revealed that $69.6 \%$ of home owners and developers cited the issue of cost as one of the major factors why precautionary measures were not taken to increase building resilience against floods. However, Escarameia et al who examined cost-benefit analysis justified the use of flood resilient building materials for the reduction of flood damage. The economic value of flood damage was estimated by rebuilding/ replacement costs, while damage reduction assessment or value is estimated by various options such as choice of resilient building materials and construction methods e.g. elevated structures [11]. Rogers et al in a similar study showed that future damage to buildings could be reduced by adopting appropriate building and foundation construction. However, they observed that the cost of building the recommended liquefaction resilient foundation was more costly than other housing foundation types but has been described as critical to building damage reduction [6]. In essence, even if cost is a factor, the cost-benefit analysis from previous studies have shown that it would be more economical to employ the use of resilient building materials and construction methods at the onset, as rebuilding or replacement costs could prove more expensive in the long run.

There are also those who did not take precautionary measures citing faith-based reasons. Their reasons were based on faith in the supernatural for protection over life and property and as such do not feel they need to take extra precautionary measures which in their opinion may only temporarily resist flood waters at best. Similarly, there are those who believe that since the 2012 floods was due to dam release, the likelihood of an extreme flood event repeating itself could only occur if such dam release were to happen again. Although, there were no facts or studies presented to back this claim, $5.4 \%$ of those who did not take precautionary measures, based their decisions on this notion. Increased sensitization campaigns by Government agencies and specialized NGOs on the need for people to take precautionary measures in-spite of their beliefs might help correct some of these ill-informed notions. Part of the problem has been traced to the fact that the building codes/ planning regulations contained no information on flood resilience and adaptation measures to act as guidelines either in professional practice or to aid the general populace with flood resilient information. Escamareia et al observed that for an effective uptake of resilience, there should be regulations to that effect backed up by legislation to make them enforceable. Only few countries in Europe namely; UK, Czech, Poland and Germany have current building regulations covering the use of flood resilient building materials. Although Norway has no specifications with regards to resilient materials, yet there are recommendations on building layout or adaptable designs such as elevation of buildings above certain levels [11].

But it is the US and Australia that currently leads in this study of resilient building materials. The US has standardized building codes updated every 3years that specifically covers the use of flood-damage resistant materials for all structures in flood hazard areas. They have also provided documentation identifying some such materials based on ability to withstand direct and prolonged contact with water, without sustaining damage 
that requires more than cosmetic repairs. They have also gone further to propose future standards that use certain methods to determine flood damage resistance ratings of materials, as well as materials that can withstand contaminants carried by flood waters [11].

With extreme flood events occurring on an ever increasing scale due to the adverse effects of climate change, there is a need to re-evaluate how buildings are constructed in this region. The study also reveals that part of the blame no matter how small, for developers not taking precautionary measures lies with the built environment professionals such as architects. With architects being the first point of call in designing flood resilient buildings, their invaluable expertise where it exists, plays a key role in the development of society's resilience to disasters like floods. This supports Haigh and Amaratunga's review on the role of built environment professionals [19]. However, there is a flip side to this issue which is a lack of consultation with professionals in the built environment in developing countries as majority of housing construction is still undertaking on owner-builder basis as observed by Anh and Phong [16]. As such, there is a need for legislation on the inclusion of a registered built environment professional when building in disaster prone areas both at the design and construction stage.

\section{Conclusions and Recommendations}

In conclusion, the study revealed that there have been some lessons learnt in post-flood building design and construction, amongst private developers and home owners in the region after the 2012 floods. The survey also indicated that a larger percentage of people who had direct previous experience of flood damage or who knew people with previous experiences of flood damage took precautionary measures to make their buildings more resilient or adaptable to flooding. This agrees with the study by DEFRA which revealed that people with some experience of household flooding are 6-times more likely to take resilience or protection measures than those with no experience. However, the data also reveals that Government involvement in sensitization as well as the level of architects' advice on flood resilience is relatively lacking. These have become factors that have warranted the decisions to either take precautionary measures or not worth studying for more holistic flood resilience in the built environment to be achieved.

Based on the discussions and subsequent conclusions given, a few recommendations have been made that if adopted could enhance flood resilience and mitigation levels within the study region. Firstly, with regards to building codes, besides the countries in Europe listed above and some others in South-east Asia not listed, there seems to be a general lack of building codes and regulations related to disaster risk reduction (DRR) in developing countries. As such, a risk-based building regulation with legal backing to create resilient structures in flood prone areas where development is predominantly owner-built is highly recommended.

Also, an aspect of flood resilient technologies (FReT) is the building aperture technology which ensures temporary watertight closure of façade openings such as doors and windows, keeping flood waters out to a defined design level. This type of technology can be adopted to aid in reducing damage by flood water ingress through apertures and openings, which is one of the major sources of damage to buildings experienced during the 2012 floods as observed by the post flood management committee (PFMC) in Bayelsa State.

Another recommendation that cannot be overemphasized is the setting, implementation and use of code specified flood levels for Yenagoa. This has been used to great effect for cities like New York [18] and Christchurch, New Zealand where current buildings are required to have floor heights above the 200 year flood level including allowance for climate change and sea level rise [6]. Similarly, after the Katrina floods, the state of Louisiana passed new building codes for floors to be raised to a minimum of $3 \mathrm{ft}$ above the highest existing adjacent grade or the local base flood elevation for new or substantially rebuilt houses [26]. In Yenagoa, the Bayelsa State Geographical Information Systems (BGIS) have set code specified flood levels for buildings based on post 2012 flood studies which should be adopted for structures in this region.

\section{REFERENCES}

[1] A. Hooijer, F. Klijn, G.B.M. Pedroli and A.G. Van Os, Towards sustainable flood risk management in the Rhine and Meuse river basins: Synopsis of the indings of IRMA-SPONGE, River Research Application, 20, 2004, 343-357

[2] E. Roy, J. Rouselle and J. Lacroix, Flood damage reduction program (FDRP) in Quebec: Case study of the Chaudiere River, Natural Hazards, 28, 2003, 387-405

[3] H. Kreibich, A.H. Thieken, T.H. Petrow, M. Muller and B. Merz, Flood loss reduction of private households due to building precautionary measures - lessons learned from the Elbe flood in August 2002, Natural Hazards and Earth System sciences 5, 2005, 117-126

[4] D. I. Smith, Actual and potential flood damage: a case for urban Lismore, NSW, Austrailia, Applied Geography, 1, 1981, 31-39

[5] T. Grothmann and F. Reusswig, People at risk of flooding: Why some residents take precautionary action while others do not, Natural Hazards 38(1-2), 2006, 101-120

[6] N. Rogers, S. Van Ballegooy, K. Williams, L. Johnson, Considering Post-Disaster Damage to Residential Building 
Construction - Is our Modern Building Construction Resilient? Proc. $6^{\text {th }}$ International Conf. on Earthquake and Geotechnical Engineering 1-4 ${ }^{\text {th }}$ Nov. Christchurch, New Zealand, 2015

[7] D. Balmforth, Flood resilient cities, Proc. of the ICE HKA Annual Seminar, Sustainable and Resilient Coastal Development, 2016

[8] T. Naumann, J. Nikolowski, S. Golz, Synthetic depth-damage functions: A detailed tool for analyzing flood resilience of building types - in E. Pasche, N. Evelpidou, C. Zevenbergen, R. Ashley and S. Garvin, (Eds.) Road map towards a flood resilient urban environment - Proceedings of the COST Action C22 Urban Flood Management in cooperation with UNESCO (IHP, Paris, France, 2009).

[9] S.L. Cutter, C.G. Burton and C.T. Enrich, Disaster resilient indicators for benchmarking baseline conditions, Journal of Homeland Security and Emergency Management, 6(4), $2010,332-344$

[10] J. Nikolowski, V. Goldberg, J. Zumm and T. Naumann, Analysing the vulnerability of buildings to climate change: Summer heat and flooding, Meteoroloische Zeitschrift, 22(2), 2013, 145-153

[11] M. Escarameia, A.F. Tagg, N. Walliman, C. Zevenbergen and F. Anvarifar, The Role of Building Materials in Improved Flood Resilience and Routes for Implementation, Proc. of the $2^{\text {nd }}$ European Conf. on Flood Risk Management, Rotterdam, The Netherlands, 19-23 Nov. 2012

[12] S. Golz, R. Schinke, T. Naumann, S. Garvin and I. White, Assessing the effects of flood resilient technologies, Proc. of the International Conf. on Flood Resilience: Experiences in Asia and Europe, 5-7 September, Exeter, United Kingdom, 2013

[13] N. Lawson, Glossary of the EU-FP7 research project 'Smart Resilient Technology, Systems and Tools' (SMARTeST) 2011

[14] B. Kolarevic, Towards architecture of Change - in Kolarevic, B and Parlac, V (Eds.) Building Dynamics: Exploring Architecture of Change, (Routledge: New York, 2015) 9-31

[15] D. Watson and M. Adams, Design for Flooding: Architecture, Landscape, and Urban Design for Resilience to Flooding and Climate Change. (John Wiley \& Sons, Inc New Jersey, 2011)

[16] T.T. Anh and T.V.G. Phong, Opportunities to Build Disaster-Resilient Shelter and Settlements: Lessons Learnt from a Housing Architectural Design Competition, Journal of Civil Engineering and Architectural Research 1(1) 2014, 24-31
[17] E. English, Amphibious foundations and the buoyant foundation project: Innovative strategies for flood-resilient housing, - in E. Pasche, N. Evelpidou, C. Zevenbergen, R. Ashley and S. Garvin, (Eds.) Road map towards a flood resilient urban environment - Proceedings of the COST Action C22 Urban Flood Management in Cooperation with UNESCO, (IHP, Paris, France, 2009).

[18] J.C.H. Aerts and W.J. Wouter Botzen, Flood-resilient waterfront development in New York City: Bridging flood insurance, building codes, and flood zoning, Annals of the New York Academy of Science, 1227, 2011, 1-82

[19] R. Haigh and D. Amaratunga, An Intergrative review of the built environment disciplines' role in the development of society's resilience to disasters, International Journal of Disaster Resilience in the Built Environment, 1(1), 2010, $11-24$

[20] B. Walker, C.S. Holling, S.R. Carpenter and A. Kinzig, Resilience, Adaptability and Transformability in Social-ecological Systems, Ecology and Society 9(2), 2004

[21] International Strategy for Disaster Reduction 2009, ISDR Secretariat retrieved from http://www.unisdr.org/eng/library/lib-terminologyenghome.htm

[22] R. Kronenburg, Flexible Architecture: Continuous and Developing - In in Kolarevic, B and Parlac, V (Eds.) Building Dynamics: Exploring Architecture of Change, (Routledge: New York, 2015) 47-66.

[23] Bayelsa State Infrastructure Advisory Committee (BSIAC) and Post Flood Management Committeee (PFMC) 2013 Flood Control Measures in Bayelsa State, Office of the Permanent Secretary, Bayelsa State Ministry of Works and Infrastructure.

[24] F. Soriwei, 2012 flood disaster cost - NEMA, 2013 retrieved from

http://www.punchng.com/news/2012-flood-disaster-cost-ni geria-n2.6th-nema/

[25] A. Blanco and J. Schanze, Conceptual and methodological frameworks for large scale and high resolution analysis of the physical flood vulnerability of buildings - In Klijn, F and Schweckendiek, T (Eds.) Comprehensive flood risk management: research for policy and practice. Proceedings of the $2^{\text {nd }}$ European Conference on flood risk management, FLOODrisk2012, (Rotterdam, The Netherlands, 2012) 19-23 November, Boca Raton: CRC press. 148-150

[26] Federal Emergency Management Agency (FEMA) 2006, Flood Recovery Guidance: Advisory Base Flood Elevations for Orleans Parish Louisiana. Washington: FEMA 